\title{
Research into diesel particulate filter passive regeneration under operating conditions
}

\author{
The paper presents the design procedure and results of computational and theoretical research of passive regeneration \\ of the diesel soot filter with a catalytic coating at different operation diesel modes. As the parameters of regeneration the \\ accumulation rate of the filter, burning rate of soot and the maximum filter temperature have been selected. The equations \\ for parameters represent a function of engine speed and its power, flow and temperature of the exhaust gases, and the \\ mass of soot accumulated in the filter. The aim of the research was to obtain the equations for regeneration parameters \\ received with the help of numerical simulation.
}

Key words: particulate matter, soot, diesel particulate filter, flow of exhaust gases, regeneration, maximum filter temperature, filter accumulation rate, soot burning rate

\section{Badania pasywnej regeneracji filtra cząstek stałych w warunkach eksploatacji}

\begin{abstract}
$W$ artykule przedstawiono procedurę projektowania $i$ wyniki obliczeń oraz badań teoretycznych pasywnej regeneracji filtra cząstek stałych z powłoka katalityczna $w$ różnych warunkach pracy silnika o zapłonie samoczynnym. Jako parametry regeneracji wybrano szybkość akumulacji, szybkość wypalania sadzy, maksymalna temperaturę filtra. Równania parametrów przedstawiono jako funkcję prędkości obrotowej silnika i jego mocy, natężenia przepływu i temperatury spalin oraz masy sadzy gromadzonej na filtrze. Podstawa badań było uzyskanie równań uwzględniających parametry regeneracji otrzymane za pomoca symulacji numerycznej.

Słowa kluczowe: cząstki stałe, sadza, filtr cząstek stałych, przepływ spalin, regeneracja, maksymalna temperatura filtra, szybkość nagromadzenia czastek na filtrze, szybkość spalania sadzy
\end{abstract}

\section{Problem formulation}

Diesel engines are widely used in vehicles because of a variety of advantages such as high performance, reliability, efficiency etc. However, the exhaust emission reduction in vehicles is still a burning issue, particularly for vehicles fitted with diesel engines. One of the basic components of diesel exhaust emissions is particulate matter (PM) which triggers a wide spectrum of negative environmental effects and has impact on human health (the origin of oncological diseases [1]). The implementation of current and future PM emission standards for vehicles with diesel engines only by modifying the engine operation is practically impossible. For this purpose, PM trapping is a necessary set of diesel soot filter or diesel particulate filter (DPF) in the engine exhaust system. Mechanical filters are the simplest and, at the same time, sufficiently effective and reliable for this purpose. These particulate filters trapping particles are in a porous layer of filter material. However, during operation of the soot filter there is a problem related to clogging of the filter material by the trapped PM. It sharply reduces the service life of the filter and deteriorates the effective parameters of the diesel engine. Therefore, filter regeneration is an actual problem. Solving the problem will enable the filters to be widely introduced in operation.

\section{Analysis of recent research and publications}

There are different methods for DPF regeneration $[2,3]$. The prospective method is the use of a catalytic coverage

\section{Sformulowanie problemu badawczego}

Silniki o zapłonie samoczynnym (ZS) są powszechnie stosowane w pojazdach dzięki wielu zaletom, jakie posiadają, wśród których można wymienić: dużą niezawodność, dużą sprawność ogólną oraz wiele innych. Istotny i nadal aktualny jest jednak problem zmniejszenia emisji składników szkodliwych spalin, zwłaszcza w pojazdach samochodowych z silnikami ZS. Jednym z podstawowych składników emisji silników ZS są cząstki stałe (PM), które negatywnie oddziałują na środowisko naturalne i zdrowie człowieka, w tym choroby nowotworowe [1]. Spełnienie obecnych i przyszłych norm emisji PM dla pojazdów z silnikami ZS jedynie przez wpływanie na pracę silnika jest praktycznie niemożliwe. W celu zmniejszenia emisji cząstek stałych jest niezbędne zastosowanie filtra sadzy lub filtra cząstek stałych (DPF) w układzie wylotowym silnika. Najprostsze konstrukcyjnie i jednocześnie wystarczająco skuteczne oraz niezawodne w działaniu są filtry mechaniczne. Filtry te zatrzymują cząstki stałe w porowatej warstwie materiału filtrującego. Jednak działanie filtra jest związane z występowaniem problemu wypełniania materiału filtrującego przez zatrzymywane cząstki. Gwałtownie zmniejsza się trwałość filtra oraz pogarszają się parametry eksploatacyjne silnika. W związku z tym rzeczywistym problemem jest zapewnienie właściwego przebiegu procesu regeneracji filtra, którego rozwiązanie pozwoli zapewnić jego szerokie wprowadzenie do eksploatacji. 
of a filter material. Thus, the burning temperature of soot essentially decreases. Since the diesel exhaust gases contain oxygen, the regeneration process can occur directly with the diesel operation in modes of sufficient exhaust temperatures. Such auto-regeneration process or passive regeneration will occur depending on several factors. Such parameters as the temperature in the filter and catalytic properties have the main impact on the soot burning process. However, less obvious parameters, such as oxygen concentration in the exhaust gases, amount of soot in the filter at a given moment, operating time on a given mode and the like also play an important role. Thus, depending on values of these parameters that under operating conditions change in time, the soot filter can be filled by PM and then be regenerated burning soot. The filter will operate for a long time, if the amount of PM and the regeneration temperature do not exceed certain permissible values. The literature describes the mathematical models and results of burning soot particles in DPFs at conditions of stationary modes [3]. The design procedures of accumulation processes and soot burning under operating conditions of vehicles fitted with diesel engines are not described.

\section{The purpose of the paper}

The purpose of this paper was to perform a research of the soot filter condition in a diesel engine vehicle at operation on different modes and their combinations. For this purpose, a design procedure was developed and a research was carried out with the help of the procedure.

The research was carried out for a diesel engine vehicle (КамА3-740M). The DPF filter with a granular filter layer was the object of the research. The granular layer was composed of granules $\left(\mathrm{WH}-2, \gamma-\mathrm{Al}_{2} \mathrm{O}_{3}\right)$ coated by the catalyst (CuO: $\mathrm{Cr}_{2} \mathrm{O}_{3}-5: 5 \%$ ). Thickness of the filter layer was 155 $\mu \mathrm{m}$ and the area of cross-section $-0.6241 \mathrm{~m}^{2}$.

\section{Materials and research results}

The engine universal characteristics as a function of the engine speed and power, values of such parameters as the flow and temperature of exhaust gases, the air excess coefficient and the concentration of soot are the initial data for the calculation process.

On the basis of the initial data the following parameters, available at different diesel operation modes, were taken into account:

1. The accumulation rate of the diesel filter

$$
\mathrm{W}_{\mathrm{H}}=\eta \mathrm{V}_{\mathrm{O} \Gamma} \mathrm{C}_{\mathrm{C}}
$$

where: $\mathrm{W}_{\mathrm{H}}$ - accumulation rate of the filter, $\mathrm{g} / \mathrm{s}, \eta-$ trapping efficiency of the filter, $\eta=0.9$ accepted in calculations, $\mathrm{V}_{\mathrm{O \Gamma}}-$ flow of exhaust gases, $\mathrm{m}^{3} / \mathrm{s}, \mathrm{C}_{\mathrm{C}}-$ soot concentration in exhaust gases, $\mathrm{g} / \mathrm{m}^{3}$.

2. Burning rate of soot was calculated for different operation under different engine modes at different DPF filling with the help of the developed and pre-tested software for calculation of the filter regeneration in stationary conditions [4].

\section{Analiza współczesnych badań i publikacji z zakresu regeneracji filtrów PM}

Istnieją różne metody regeneracji filtra DPF [2, 3]. Perspektywiczną metodą jest pokrycie warstwą katalityczną materiału filtracyjnego, w wyniku czego temperatura spalania sadzy zmniejsza się znacząco. Z uwagi na to, że spaliny silników ZS zawsze zawierają tlen, proces regeneracji filtra może nastąpić podczas pracy silnika, w warunkach osiągnięcia odpowiedniej temperatury spalin. Powyższy proces automatycznej lub pasywnej regeneracji będzie przebiegać w różny sposób, w zależności od kilku czynników. Główny wpływ na proces wypalania sadzy mają temperatura filtra i właściwości katalizatora. Jednak istotną rolę odgrywają także inne, mniej oczywiste parametry, takie jak stężenie tlenu w spalinach, ilość sadzy w filtrze, czas pracy w określonym trybie i inne. W zależności od wartości powyższych parametrów, które zmieniają się w czasie, kiedy filtr sadzy jest wypełniony przez cząstki PM następuje proces wypalania sadzy. Filtr będzie pracował przez długi czas, jeśli ilość cząstek PM w nim zawartych i temperatura regeneracji nie przekroczą określonych dopuszczalnych wartości. W literaturze opisano modele matematyczne i wyniki badań dotyczących wypalania cząstek stałych w filtrze DPF w warunkach stacjonarnych [3]. Obecnie brak jest procedur projektowania procesów gromadzenia i wypalania sadzy w rzeczywistych warunkach pracy silników ZS stosowanych w pojazdach samochodowych.

\section{Cel pracy}

Celem pracy jest przedstawienie wyników badań stanu filtra PM silnika ZS pojazdu podczas różnych jego warunków pracy i ich kombinacji. W tym celu opracowano procedurę projektowania, na podstawie której przeprowadzono stosowne badania.

Badania wykonano dla pojazdów samochodowych wyposażonych w silniki ZS (KamAZ-740M). Obiektem badań był filtr DPF z granulowanym złożem filtrującym. Granulowane złoże składało się z granulek $\left(\mathrm{SHN}-2, \gamma-\mathrm{Al}_{2} \mathrm{O}_{3}\right)$ i pokryte było katalizatorem $\left(\mathrm{CuO}: \mathrm{Cr}_{2} \mathrm{O}_{3}-5: 5 \%\right)$. Grubość złoża filtra wynosiła $155 \mu \mathrm{m}$, przekrój - 0,6241 $\mathrm{m}^{2}$.

\section{Materiały i wyniki badań}

Danymi wyjściowymi do obliczeń podstawowych charakterystyk silnika w funkcji prędkości obrotowej i wartości mocy były takie wielkości, jak: natężenie przepływu i temperatura spalin, współczynnik nadmiaru powietrza oraz stężenie sadzy.

Na podstawie danych wyjściowych dostępnych dla różnych punktów pracy silnika ZS określono:

1. Szybkość akumulacji cząstek na filtrze - wzór (1), gdzie: $\mathrm{W}_{\mathrm{H}}$ - szybkość gromadzenia się cząstek na filtrze, g/s, $\eta$ - sprawność filtra; w obliczeniach przyjęto: $\eta=0,9$, $\mathrm{V}_{\mathrm{OГ}}$ - objętościowe natężenie przepływu spalin, $\mathrm{m}^{3} / \mathrm{s}$, $\mathrm{C}_{\mathrm{C}}$ - stężenie sadzy w spalinach, $\mathrm{g} / \mathrm{m}^{3}$.

2. Szybkość wypalania sadzy; obliczono ją dla różnych warunków pracy silnika $\mathrm{ZS}$ z różnym napełnieniem filtra DPF za pomocą przygotowanych i zweryfikowanych 
3. The maximum filter temperature while burning soot is a parameter that most essentially influences the durability of a DPF. The temperature was determined, juxtaposed with the burning rate of soot by mathematical modeling of a regeneration process for different modes and filter filling.

After processing the results of these calculations using the least squares method correlations were drawn up. The equations for parameters represent a function of the engine speed and its power, flow and temperature of exhaust gases and mass of soot collected in the filter. Good approximation is given with the following equations:

$$
\begin{aligned}
\mathrm{W}_{\mathrm{H}}= & 1.1195 \cdot \exp (-8.6196-0.000206 \mathrm{n} \\
& \left.+0.000000422 \mathrm{n}^{2}+0.01323 \mathrm{P}+0.000183 \mathrm{P}^{2}\right) \\
\mathrm{W}_{\mathrm{B}}= & 30.8 \cdot \exp \left(-7.79+\frac{139101}{\mathrm{G}^{2}}-\frac{109784}{\mathrm{~T}^{2}}-0.01549 \alpha^{2}+\right. \\
+ & 0.00305 \mathrm{~m}-0.8484 \frac{\alpha}{\mathrm{m}}+0.000157 \frac{\mathrm{T}^{2}}{\mathrm{G}}+ \\
\left.0.00000826 \alpha \mathrm{T}^{2}+0.000489 \frac{\mathrm{G}}{\mathrm{m}}-0.00754 \frac{\mathrm{T}}{\mathrm{m}}\right) & \\
\mathrm{T}_{\max }= & 271.1+\frac{13908939}{\mathrm{G}^{2}}-\frac{7754221}{\mathrm{~T}^{2}}+0.6554 \alpha^{2}+ \\
+ & 0.7884 \mathrm{~m}-0.07072 \alpha \mathrm{m}+0.00000084 \mathrm{GT}^{2}+ \\
+ & 0.000074 \alpha \mathrm{T}^{2}-0.000226 \mathrm{Gm}-0.00034 \mathrm{Tm}
\end{aligned}
$$

where: $\mathrm{W}_{\mathrm{B}}$ - burning rate of soot, $\mathrm{g} / \mathrm{s} ; \mathrm{n}$ - engine speed, $\min ^{-1} ; \mathrm{P}$ - relative engine power, $\% ; \mathrm{G}$ - flow of exhaust gases, $\mathrm{kg} / \mathrm{h} ; \alpha$ - excess air coefficient; $\mathrm{m}$ - initial soot mass in the filter, $\mathrm{g} ; \mathrm{T}$ - temperature of exhaust gases in operation modes, ${ }^{\circ} \mathrm{C} ; \mathrm{T}_{\max }-$ maximum filter temperature, ${ }^{\circ} \mathrm{C}$.

The correlation factors for the equations (2), (3) and (4) are: $0.991 ; 0.987 ; 0.981$, accordingly.

Calculation of the filter accumulation rate was carried out according to the test cycle and with the equation (1).

According to equation (2) a characteristic of accumulation rate $\mathrm{W}_{\mathrm{H}}$ for different diesel operation modes was developed, which represents an exponential dependence on the engine speed and relative engine power. Fig. 1 shows that $\mathrm{W}_{\mathrm{H}}$ essentially increases with the increasing engine power at high engine speed.

The computer experiments were carried out to determine the burning rate of soot in the filter and the maximum filter temperature. The experiment was executed with the use of the program «BurnSootFilter» of a catalytic thermal regeneration of the filter developed by Y. Shekhovtsov.

According to equations (3) and (4), the characteristics of the burning rate of soot wcześniej programów do obliczeń regeneracji filtra w warunkach stacjonarnych [4].

3. Maksymalną temperaturę wypalania sadzy - ma ona istotny wpływ na trwałość filtrów DPF. Wyznaczono ją $\mathrm{w}$ procesie matematycznego modelowania regeneracji, opierając się na różnej szybkości wypalania sadzy, dla różnych trybów pracy i napełniania filtra.

Po opracowaniu wyników obliczeń za pomocą metody najmniejszych kwadratów uzyskano kolejne zależności. Równania parametrów przedstawiają funkcję masy sadzy gromadzonej w filtrze zależną od prędkości obrotowej silnika i jego mocy oraz przepływu i temperatury spalin. Dobrą aproksymację dają równania (2)-(4), gdzie: $\mathrm{W}_{\mathrm{B}}$ - szybkość akumulacji sadzy, g/s, n - prędkość obrotowa silnika, obr/min, P - względna moc silnika, \%, G-masowe natężenie przepływu spalin, $\mathrm{kg} / \mathrm{h}, \alpha$ - współczynnik nadmiaru powietrza, $\mathrm{m}$ - początkowa masa sadzy na filtrze, g, T - temperatura spalin, ${ }^{\circ} \mathrm{C}, \mathrm{T}_{\max }-$ maksymalna temperatura filtra, ${ }^{\circ} \mathrm{C}$.

Współczynnik korelacji dla równań (2)-(4) wynosi odpowiednio: 0,991,0,987, 0,981. Obliczenia szybkości akumulacji cząstek w filtrze przeprowadzono zgodnie $\mathrm{z}$ cyklem badań dla równania (1).

Zgodnie z równaniem (2) zbudowano charakterystykę szybkości akumulacji $\mathrm{W}_{\mathrm{H}}$ dla różnych warunków pracy silnika ZS, będącą wykładniczą funkcją zależną od prędkości obrotowej silnika i jego względnej mocy. Na rysunku 1 przedstawiono, że $\mathrm{W}_{\mathrm{H}}$ znacznie zwiększa swoją wartość wraz ze wzrostem mocy silnika w zakresie dużych wartości jego prędkości obrotowej.

W celu określenia szybkości wypalania sadzy w filtrze i maksymalnej temperatury filtra przeprowadzono odpowiednie badania numeryczne. Obliczenia dla katalitycznej termicznej regeneracji filtra wykonano za pomocą programu BurnSootFilter opracowanego przez Y. Shekhovtsova.

Zgodnie z równaniem (3) i (4) zbudowano charakterystyki szybkości wypalania sadzy i maksymalnej temperatury filtra dla różnych warunków pracy silnika. Na rysunku 2 przedstawiono wykładniczą zależność szyb-

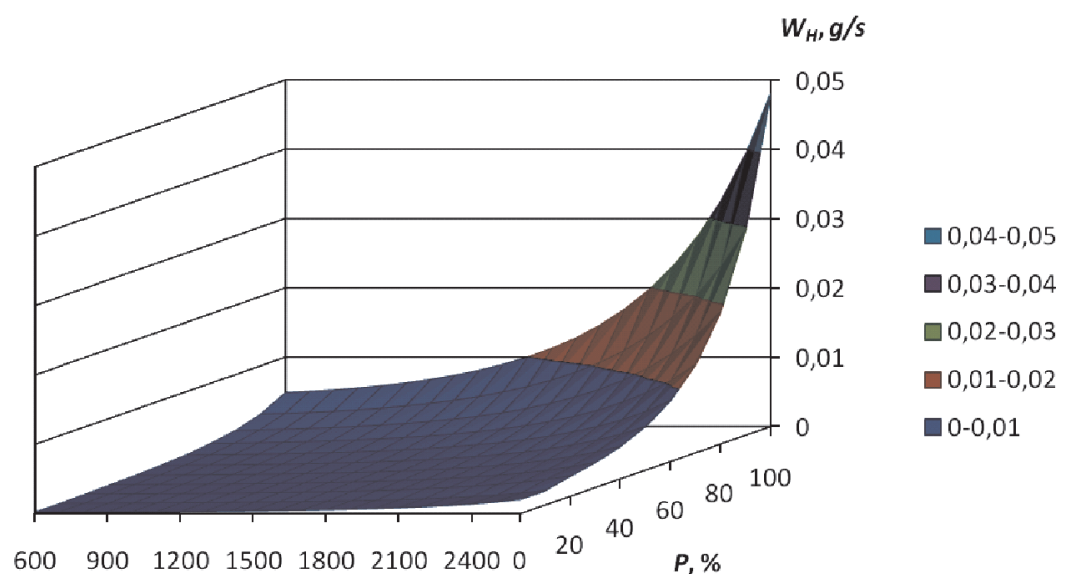

$n, m^{-1}$

Fig. 1. The characteristic of a soot accumulation rate for diesel engine Rys. 1. Charakterystyka szybkości gromadzenia sadzy na filtrze silnika ZS 


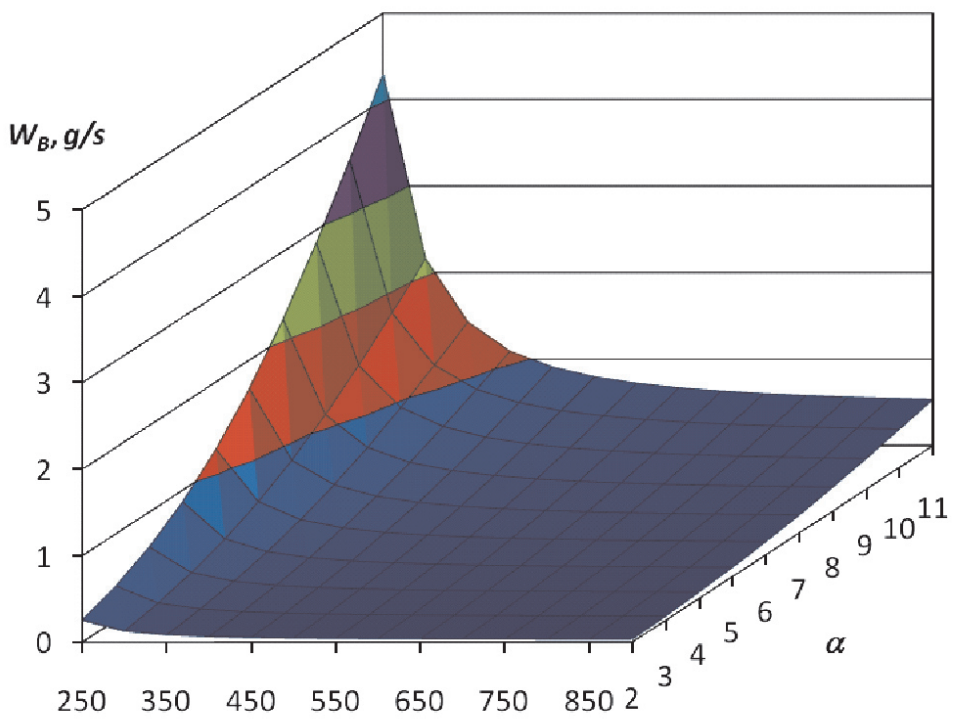

$\mathrm{G}, \mathrm{kg} / \mathrm{h}$

Fig. 2. The characteristic of the soot burning rate at the exhaust gas temperature $\left(\mathrm{T}=250^{\circ} \mathrm{C}\right)$ for a $500 \mathrm{~g}$ initial soot mass in the filter

Rys. 2. Charakterystyka szybkości wypalania sadzy przy temperaturze spalin $T=250^{\circ} \mathrm{C}$ i dla początkowej masy sadzy w filtrze równej $500 \mathrm{~g}$ kości wypalania sadzy od natężenia przepływu spalin i współczynnika nadmiaru powietrza. Szybkość wypalania sadzy zasadniczo zwiększa się wraz ze wzrostem współczynnika nadmiaru powietrza i zmniejszeniem 3-4 natężenia przepływu spalin. ZaQ2-3 leżność maksymalnej temperatury 1-2 filtra od natężenia przepływu spalin i współczynnika nadmiaru powietrza przedstawiono na rys. 3 .

Na podstawie przeprowadzonych badań równań można wyciągnąć następujące wnioski:

1. Na biegu jałowym i w zakresie małych wartości prędkości obrotowych silnika obserwuje się małą szybkość akumulacji cząstek w filtrze dla wszystkich zakresów obciążenia silnika. Ilość pozostałego tlenu w spalinach jest wystarczająca do procesu wypalania sadzy, ale proces powyższy nie występuje ze względu na małą wartość temperatury spalin.

2. Podczas pracy silnika $w$ zakresie

and maximum filter temperature for different diesel operation modes were developed. Figure 2 shows the exponential dependence of the burning rate of soot from the flow of exhaust gases and air excess coefficient. The burning rate of soot essentially increases with the increasing excess air coefficient and with the decreasing flow of the exhaust gases. Figure 3 shows a dependence of the maximum filter temperature on the flow of exhaust gases and excess air coefficient.

According to the analysis of the equations, the following conclusions can be drawn:

1. Low accumulation rates of the filter for the whole range of engine loads were observed at the engine idling and low speed modes. Amount of residual oxygen in the exhaust gases is sufficient for combustion, but the burning of soot does not occur because of the low temperature of the exhaust gases.

2. The accumulation of soot does not occur at the minimum filling of the filter and engine operation at part load modes. The burning rate of soot exceeds the accumulation rate of the filter. Soot burns at the maximum filter filling, because the increase of the engine load increases the exhaust temperatures and the burning rate of soot.

3. The accumulation of soot does not occur at the minimum filling of a filter and engine operation at full power and low engine speed. The burning rate of soot exceeds the accumulation rate of the filter. Fast soot burning occurs at the maximum filter filling. It is related to the high temperature

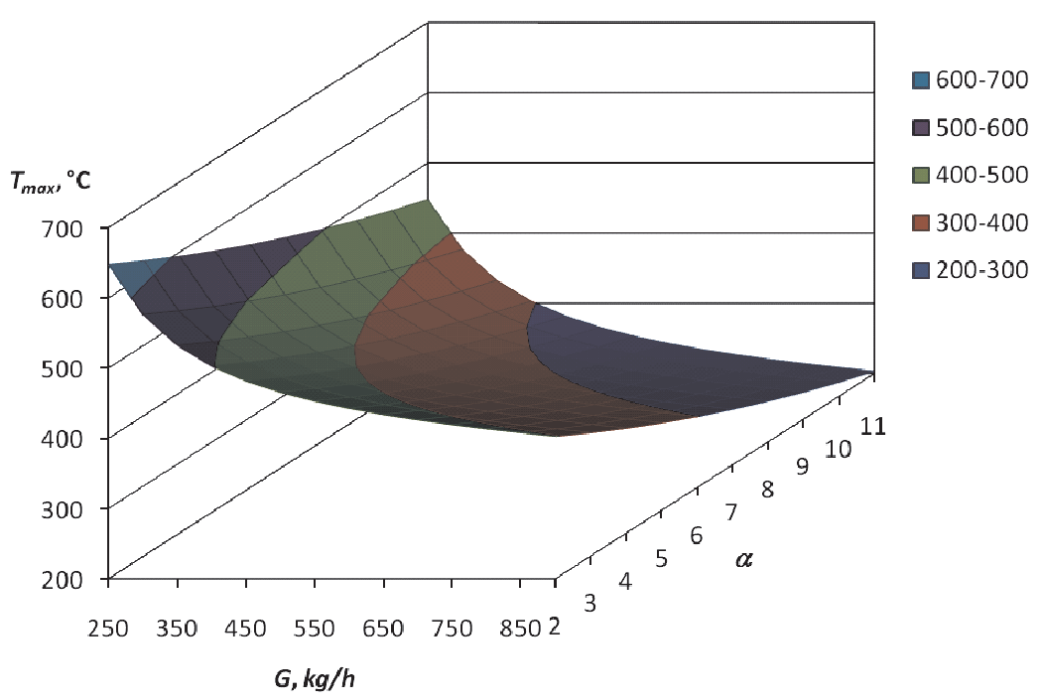

Fig. 3. The characteristic of the maximum filter temperature at the exhaust gas temperature $\left(\mathrm{T}=250^{\circ} \mathrm{C}\right.$ ) for $500 \mathrm{~g}$ initial soot mass in the filter

Rys. 3. Charakterystyka maksymalnej temperatury filtra dla temperatury spalin $T=250^{\circ} \mathrm{C}$ oraz początkowej masy sadzy w filtrze równej $500 \mathrm{~g}$ 
of the exhaust gases and a sufficient content of residual oxygen.

During operation of a vehicle fitted with a diesel engine the amount of accumulated PM in the filter was determined with the help of a numerical integration of a differential equation:

$$
\mathrm{m}=\mathrm{m}_{\mathrm{H}}+\int_{0}^{\mathrm{t}}\left(\mathrm{W}_{\mathrm{H}}-\mathrm{W}_{\mathrm{B}}\right) \mathrm{dt}
$$

where: $\mathrm{m}_{\mathrm{H}}$ - initial soot mass in the filter, $\mathrm{g} ; \mathrm{t}$ - engine operation time, $\mathrm{s}$.

The computer software was developed by using the proposed design procedure (the Excel workbook). The program allows analyzing of the filter condition during its operation for different modes and their combinations.

The calculation results showed that even in the presence of the catalytic coating at idling modes and low loads (until $15-25 \%$ powers) the burning of soot in the filter layer does not take place. PM only accumulates at these modes according to equation (1). Modes with power of more than $25 \%$ have higher exhaust temperatures and a higher flow of PM in the filter, and under these modes the PM is burnt in the layer of a filter material. Thus, if accumulation rate of the diesel filter on the set mode is constant, the burning rate of

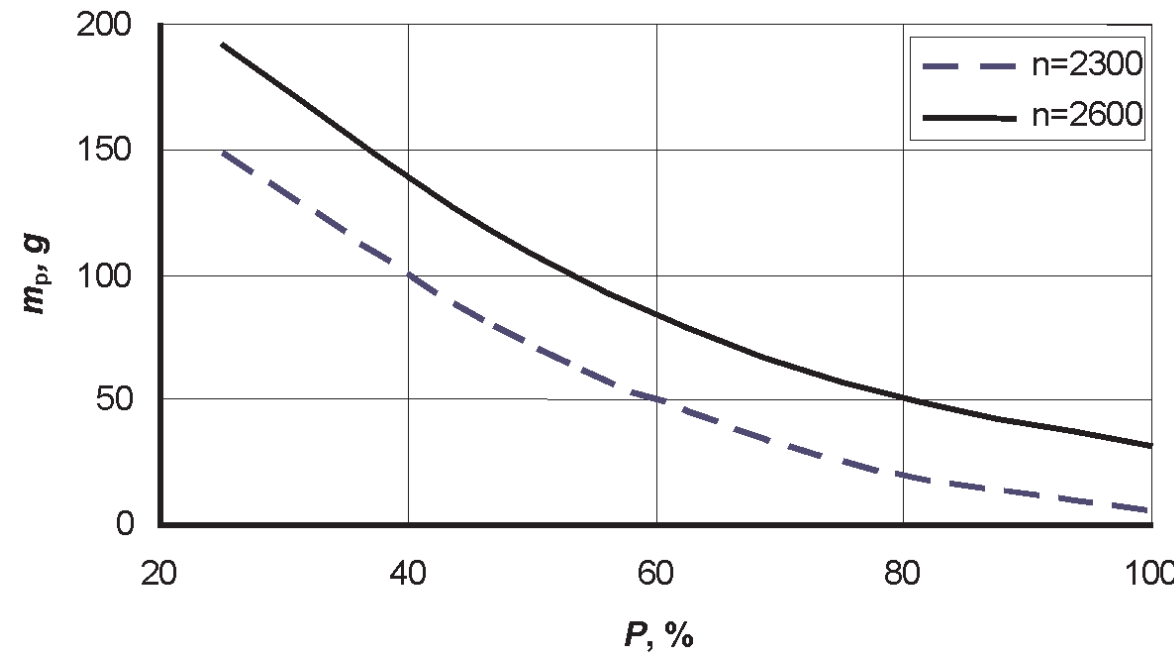

Fig. 4. The equilibrium soot mass in the filter Rys. 4. Przebieg zmian równowagowej masy sadzy w filtrze pracy silnika, s. pełnieniem filtra. Szybkość wypalania sadzy przekracza szybkość jej akumulacji w filtrze. Przy maksymalnym wypełnieniu filtra cząstkami występuje szybkie wypalanie sadzy. Źródłem tego jest wysoka temperatura spalin i wystarczająca ilość tlenu.

Ilość zgromadzonych cząstek PM w filtrze podczas pracy silnika ZS w pojeździe wyznaczono za pomocą numerycznego całkowania równania różniczkowego (5), gdzie: $\mathrm{m}_{\mathrm{H}}$ - początkowa masa sadzy w filtrze, $\mathrm{g}, \mathrm{t}$ - czas

Program numeryczny opracowano, opierając się na proponowanej procedurze projektowania z zastosowaniem programu Excel. Program pozwala na badanie stanu filtra podczas jego pracy w różnych trybach i ich kombinacjach.

Wyniki obliczeń wskazały, że wypalanie sadzy w filtrze z obecną katalityczną warstwą nie występuje podczas pracy silnika na biegu jałowym i w zakresie niewielkich obciążeń (do 15-25\% mocy). Zgodnie z równaniem (1) cząstki PM gromadzą się podczas pracy silnika w powyższych warunkach. Tryby pracy silnika o względnej mocy ponad $25 \%$ mają większą temperaturę spalin i generują przepływ cząstek PM w filtrze, co powoduje ich wypalanie w złożu materiału filtrującego. Tak więc, jeśli szybkość gromadzenia się cząstek PM w filtrze w wyznaczonym trybie jest stała, szybkość wypalania sadzy na skutek zmian ilości PM znajdujących w filtrze zmienia się. Jeżeli wartość emisji PM będzie mniejsza niż określona wartość $m_{p}$, szybkość wypalania $\mathrm{W}_{\mathrm{B}}$ będzie mniejsza od szybkości akumulacji $\mathrm{W}_{\mathrm{H}} \mathrm{i}$ ilość nagromadzonych cząstek PM w filtrze wzrośnie. Jednakże przyrost masy $\mathrm{m}$ zwiększa $\mathrm{W}_{\mathrm{B}}$. Później szybkość akumulacji PM wyrównuje się $\mathrm{z}$ szybkością wypalania, co powoduje, że masa cząstek PM w filtrze jest niezmienna i równa się $\mathrm{m}_{\mathrm{p}}$. Gdy $\mathrm{m}_{\mathrm{H}}>\mathrm{m}_{\mathrm{p}}$, wtedy $\mathrm{m}_{\mathrm{p}}$ zachowuje się podobnie. Tylko w tym przypadku $\mathrm{W}_{\mathrm{B}}$ będzie się zmniejszać, dopóki nie wyrówna się z $\mathrm{W}_{\mathrm{H}}$. Na rysunku 4 pokazano zmiany równowagi cząstek PM w filtrze, $m_{p}$ w zależności od charakterystyki obciążenia silnika ZS dla dwóch prędkości obrotowych silnika (n, obr/min).

soot changes due to the changes in the amount of PM located in the filter. If the initial amount of PM is less than value $\mathrm{m}_{\mathrm{p}}$, the burning rate $\mathrm{W}_{\mathrm{B}}$ will be lower than the accumulation rate $\mathrm{W}_{\mathrm{H}}$ and the amount of the accumulated PM in the filter will increase. However, the increase in mass $m$ increases $\mathrm{W}_{\mathrm{B}}$. Later time is equaled with the accumulation rate of $\mathrm{PM}$ and the burning rate. Subsequently, the mass of PM in the diesel filter is invariable and is equal to $m_{p}$. In the case where there is $m_{H}>m_{p}$, then $m_{p}$ is established similarly. Only in this case, $\mathrm{W}_{B}$ will decrease until it equals $\mathrm{W}_{\mathrm{H}}$. Fig. 4 shows the influence of the change in the equilibrium amount of PM
Zależności dla innych prędkości obrotowych są podobne.

Zwiększenie mocy silnika ZS powoduje zmniejszenie ilości PM w filtrze ze względu na zwiększenie temperatury spalin. Prowadzi to do zwiększenia szybkości wypalania sadzy. Przy małych prędkościach obrotowych silnika występuje zmniejszenie szybkości akumulacji cząstek w filtrze $\mathrm{W}_{\mathrm{H}}$, co powoduje zmniejszenie $\mathrm{m}_{\mathrm{p}}$.

Spalanie sadzy może spowodować znaczny wzrost temperatury warstwy filtrującej, a to może być przyczyną uszkodzenia filtra (np. badania reaktora katalitycznego z ziarnistym złożem filtrującym przy maksymalnym zapeł- 
in the filter $m_{p}$ on the load characteristics of the diesel engine for the two engine speeds $\left(\mathrm{n}, \mathrm{min}^{-1}\right)$. A similar situation is for other speeds.

An increase in power in a diesel engine leads to a decrease in the amount of PM in the filter due to the increase of the exhaust gases temperature. This leads to an increase of the burning rate of soot. The $\mathrm{m}_{\mathrm{p}}$ reduction at lower speeds is caused by a decrease in the accumulation rate of the diesel filter $\mathrm{W}_{\mathrm{H}}$.

Burning of soot can lead to a significant increase of the temperature in the filter layer. This may cause the filter failure. Tests carried out on the catalytic converter with the granular filter layer and a maximum loading soot are the case here [5] where an exhaust gas heater was installed before the converter. The temperature of the exhaust gases was increased slowly in the heater

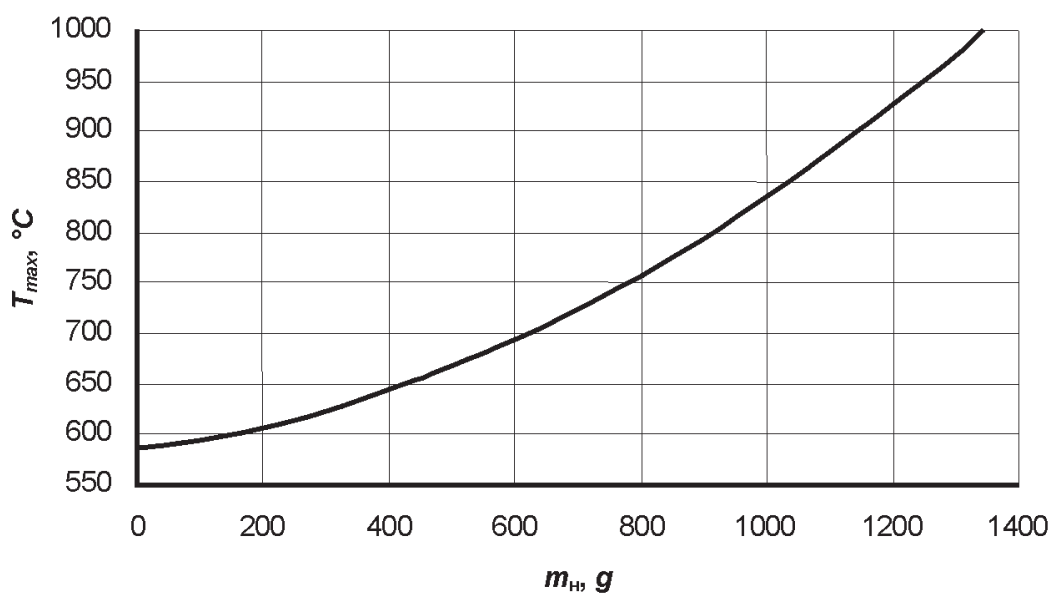

Fig. 5. The relation of the maximum temperature in the filter layer and the initial soot mass in the filter

Rys. 5. Zależność maksymalnej temperatury warstwy filtrującej od początkowej masy sadzy na filtrze

to activate the early burning of soot. At the temperature of about $225{ }^{\circ} \mathrm{C}$ a sharp increase in the temperature filter layer was recorded. The temperature in the layer was at $1250{ }^{\circ} \mathrm{C}$. Two of the three thermocouples located in the layer failed.

High content of PM in the diesel filter leads to an uncontrolled process of soot burning and damage of the filter element. Diesel soot filter is out of operation. In such a situation the filter should be given the maximum possible flow of exhaust gas in order to distribute the heat between the exhaust gases and the filter element. Such modes of regeneration are disadvantageous and are to be avoided.

The maximum temperature in the filter layer depends not only on the exhaust gases temperature. The accumulated soot mass in the diesel filter at the beginning of the regeneration can have a great influence on its value. This situation can occur when the engine is transferred to the nominal rating mode or the one similar to it or when the engine is operated for a long time at the idle mode or the one similar to it without regeneration. In this case fast burning of the previously accumulated soot can lead to a heat stroke and a damage of the filter layer. Figure 5 shows the maximum temperature in the filter layer from the soot initial mass in the filter during its regeneration in the nominal mode of the engine operation.

Figure 5 shows that when the filter is loaded more than 1200 grams high temperatures will occur in the filter layer. In operating modes, the accumulation of such PM mass in the filter may not occur as the engine would have to operate at low load continuously for more 100 hours. The passive regeneration of the filter for diesel engines at lower modes can occur so slowly that the accumulation rate of PM in the filter element will be higher. This leads to the disadvantageous filling of the filter. Therefore, it is advisable to forecast such situations and avoid excessive filter filling.

nieniu sadzą) [5]. Przed reaktorem zainstalowano grzejnik spalin. Grzejnik powoli zwiększa temperaturę spalin, aby uruchomić wcześniejsze wypalanie sadzy. Przy temperaturze około $225^{\circ} \mathrm{C}$ odnotowano gwałtowny wzrost temperatury złoża filtra. Temperatura złoża wynosiła $1250^{\circ} \mathrm{C}$. Dwie z trzech termopar znajdujących się w złożu uległy uszkodzeniu.

Wysoka zawartość cząstek PM w filtrze prowadzi do niekontrolowanego procesu wypalania sadzy i niszczenia filtra. Uniemożliwia to eksploatację filtra sadzy silnika ZS. W takiej sytuacji powinien być uzyskany jak największy przepływ spalin, w celu rozprowadzania ciepła między spalinami i elementami filtra. Takie sposoby regeneracji są nieprawidłowe i należy ich unikać.

Maksymalna temperatura złoża filtrującego zależy nie tylko od temperatury spalin. Na powyższą wartość może mieć duży wpływ masa nagromadzonej sadzy w filtrze silnika ZS przed rozpoczęciem procesu regeneracji. Powyższa sytuacja może wystąpić wtedy, gdy silnik długi czas pracował bez regeneracji na biegu jałowym lub w warunkach bliskich powyższemu punktowi pracy i gdy warunki pracy silnika zmieniły się na nominalne lub im podobne. Wtedy szybkie wypalanie wcześniej zgromadzonej sadzy może prowadzić do gwałtownego zwiększenia temperatury i zniszczenia złoża filtrującego. Na rysunku 5 przedstawiono maksymalną temperaturę złoża filtrującego w zależności od początkowej masy sadzy w filtrze podczas regeneracji dla warunków znamionowych pracy silnika.

Wypełnienie filtra cząstkami o masie ponad $1200 \mathrm{~g}$ (rys. 5) powoduje wystąpienie dużych wartości temperatur warstwy filtrującej. Nagromadzenie takiej masy cząstek PM w filtrze podczas pracy silnika nie występuje, ponieważ silnik musi pracować przy małym obciążeniu przez okres dłuższy niż 100 godzin. Pasywna regeneracja filtra silnika ZS podczas pracy w zakresie małych wartości obciążenia może występować tak wolno, że szybkość gromadzenia cząstek PM w filtrze będzie większa. Prowadzi to do nadmiernego 


\section{Conclusions}

1. Preliminary calculations show that under vehicle operating conditions the operating diesel engine modes do not lead to hazardous concentrations of soot in the filter.

2. Our research shows, that the use of the catalytic coating in the soot filter ensures its passive regeneration in the operating conditions.

3. The main factors determining the regeneration of the filter are the flow of the exhaust gases through the filter element, the temperature of the exhaust gases and exhaust gas oxygen content.

4. There are modes of engine operation, for which the equations describe the regeneration incorrectly. This problem can be solved by replacement of the universal engine characteristics with the extended plan of the design experiment subject to unreported modes.

5. The theoretical importance of the research is to obtain the dependences of the accumulation rate, burning rate and the maximum filter temperature on the operational parameters of the diesel engine.

6. The practical importance of the research is the possibility of analysis of the conditions of the filter in different modes as well as to simulate different operating conditions without the use of specific characteristics of the diesel engine.

Paper reviewed/Artykut recenzowany wypełnienia filtra cząstkami. Dlatego wskazane jest przewidywanie takich sytuacji w celu uniknięcia nadmiernego wypełnienia filtra.

\section{Wnioski}

1. Obliczenia wstępne wskazują, że praca silnika ZS zainstalowanego w pojeździe nie prowadzi do niebezpiecznych koncentracji sadzy w filtrze PM.

2. Badania autorów pokazują, że zastosowanie filtra sadzy z powłoką katalityczną zapewnia pasywną regenerację w warunkach eksploatacji.

3. Głównymi czynnikami określającymi regenerację filtra są: natężenie przepływu spalin przez element filtrujący, temperatura spalin i ilość zawartego w nich tlenu.

4. Istnieją warunki pracy silnika, dla których równania opisujące proces regeneracji są nieprawidłowe. Powyższy problem może być rozwiązany przez rozszerzony plan badań i uzupełnienie charakterystyk silnika podczas pracy w tych warunkach.

5. Teoretyczny aspekt powyższych badań to uzyskanie zależności szybkości akumulacji, szybkości spalania i maksymalnej temperatury filtra od parametrów silnika ZS.

6. Praktycznym aspektem badań jest możliwość oceny stanu filtrów w różnych warunkach, również do symulowania tychże warunków bez zastosowania szczególnych charakterystyk silnika $\mathrm{ZS}$.

\section{Bibliography/Literatura}

[1] Zvonov V.A., Kornilov G.S., Simonova E.A.: Ocenka i kontrol' vybrosov dispersnyh častic otrabotavših gazov dizelej. Izd. Prima-Press-M, 2005, 312 s.

[2] Šehovcov U.I., Zaigraev L.S., Popov A.S.: Analiz metodov regeneracii fil'truûsih èlementov dizel'nyh saževyh fil'trov,

Leonid Zaigrayev, DEng. - East-Ukrainian National University of the Volodymyr Dahl, Department of Ecology, Ukraine.

Dr inż. Leonid Zaigrayev - docent na WschodnioUkrainskim Narodowym Uniwersytecie im. Władimira Dalii, Wydziat Ekologii, Ukraina.

e-mail: zaigraevl@yandex.ua

Yury Shekhovtsov, MSc. - East-Ukrainian National University of the Volodymyr Dahl, Department of Ecology, Ukraine.

Mgr inż. Yury Shekhovtsov - asystent na Wschodnio-Ukrainskim Narodowym Uniwersytecie im. Władimira Dalii, Wydziat Ekologii, Ukraina.

e-mail: murenay@ukr.net
Èkologiâ: Sbornik naučnyh trudov Vostočnoukrainskogo Nacional'nogo Universiteta im. V. Dalâ i Poznan'skogo Tehničeskogo Universiteta - Lugansk: Izd. VNU im. V. Dalâ. 2002 - No 2 - s. 84-96.

[3] Merkisz J., Mazurek S.: Pokładowe systemy diagnostyczne pojazdów samochodowych OBD. 2006, $608 \mathrm{~s}$.

[4] Šehovcov Û.I., Zaigraev L.S.: Matematičeskaâ model' vygoraniâ tvërdyh častic v strukture dizel'nogo saževogo fil'tra, Aviacionno-kosmičeskaâ technika i tehnologiâ - Har'kov, 2003, vyp. 7 (42), s. 16-19.

[5] Zvonov V.A., Zaigraev L.S., Vasil'ev I.P., Bodrov Û.K.: Èlektromehaničeskij fil'tr dlâ ulavlivaniâ tvërdyh častic iz otrabotavših gazov dizelâ//Èkotehnologii i resursosbereženie, 1996, No 4, s. 59-64.

Oleg Ignatov, DEng. - East-Ukrainian National University of the Volodymyr Dahl, Department of Ecology, Ukraine.

Dr inż. Oleg Ignatov-docent na Wschodnio-Ukraińskim Narodowym Uniwersytecie im. Władimira Dalii, Wydzial Ekologii, Ukraina.

e-mail:murenay@ukr.net 